РАДИШЕВСЬКА О.Р.

\title{
ГЕНЕЗИС ПОНЯТТЯ «ЕВРОПЕЇЗАЦЯ»: ЗАГАЛЬНОГУМАНІТАРНИЙ ТА ПРАВОВИЙ ДИСКУРС
}

У статті досліджено поняття «європеїзація» в загальногуманітарному та правовому дискурсах. Зазначено, що поняття «європеїзація» (англ. «Europeanization») 3'явилося в англомовній літературі про політичну інтеграцію в Європі, де ще в 90-х роках минулого століття гостро стояло питання про те, чи впливає інтеграційний процес на інституційну трансформацію національних держав, що беруть участь у ньому. Межі понятійного контексту вживання цього поняття окреслені такими термінами, як європейська інтеграція, наднаціональність, інституціоналізм, багаторівневе адміністрування, Європейський Союз. Найчастіше європеїзацію трактують як соціально-культурне запозичення форм, властивих західноєвропейському устрою. Саме тому, на думку вчених, одним з основних аспектів студій європеїзації $\epsilon$ модель так званої «присутності Європейського Союзу», де норми ЄС у чистому вигляді експортуються в національну політику. Під європеїзацією як історичним феноменом розуміють «експорт» європейської влади і соціальних норм: інституціональна організація і практика, соціальні та культурні традиції, цінності, поведінка. Наголошено, що в академічному дискурсі з міжнародних відносин європеїзація символізує поширення у світі загальноєвропейської політики, права, культури та інших цінностей, аби їх сприймали інші народи, держави і спільноти. Зроблено висновок, що поняття «європеїзація» багатогранне і багатовекторне, в якому існують різні напрями іiї реалізації. Європеїзація, як правило, розуміється як ієрархічний (англ. «top-down») підхід, що концентрується на перенесенні норм і правил СС і Ради Європи на рівень інших держав. Використання терміна «європеїзація права» для вивчення нових рис європейської інтеграції пов'язане із т.зв. «системним ефектом» європейських регіональних організацій, тобто зворотного впливу наднаціональної системи адміністрування, створеної в Європі, на національні структури їх держав-членів.

Ключові слова: європеїзачія, європейська інтеграчія, вестернізачія, європейські циінності, публічне адміністрування, адміністративне право.

The present article explores the notion of in humanitarian and legal discourses. It is noted that the concept of "Europeanization" appeared in the English literature on political integration in Europe, where as early as in the 1990s the question was raised as to whether the integration process had an impact on the institutional transformation of nation-states. The boundaries of the conceptual context of application of this concept are defined by such terms as European integration, supranationality, institutionalism, multilevel administration, the European Union.

Very often Europeanization is interpreted as a socio-cultural borrowing of forms inherent in the Western European system. That is why one of the main aspects of Europeanization studies is the model of the so-called "presence of the European Union", where EU rules are purely exported to national politics. Europeanization is understood as a historical phenomenon by the "export" of European power and social norms: institutional organization and practice, social and cultural traditions, values, behavior. It is emphasized that in the academic discourse on international relations Europeanization symbolizes the spread of pan-European politics, law, culture and other values in the world to be perceived by other peoples, states and communities. It is concluded that the

(С РАДИШЕВСЬКА О.Р. - кандидат юридичних наук, доцент кафедри адміністративного права юридичного факультету (Київський національний університет імені Тараса Шевченка), суддя (Касаційний адміністративний суд у складі Верховного Суду) 
concept of Europeanization is multifaceted and multi-vector with different directions of its implementation. Europeanization is usually understood as a hierarchical (top-down) approach that focuses on transposing rules and regulations of EU and Council of Europe to other countries. The use of the term "Europeanisation of law" for studing new features of European integration linked to the so-called "systemic effect" of European regional organizations - the reverse influence of a supranational system of administration in Europe on the national structures of their Member States.

Key words: Europeanization, European integration, Westernisation, European values, public administration, administrative law.

Вступ. Поняття «європеїзація» доволі актуальне для сьогочасної України. Українці-європейська нація з високим рівнем розвитку культури, науки й освіти. Водночас доля розпорядилася так, що впродовж століть ми перебували в різних державних утвореннях, із різними традиціями i в різних геополітичних зв'язках з європейськими країнами. Це призвело до різного бачення доцільності інтегрування в європейську спільноту, різного розуміння ії переваг i, зрештою, різної готовності до сприйняття і особливо дотримання цінностей, необхідних для членства в Свропейському Союзі. Усвідомлення цих відмінностей створює основу для розробки політики європеїзації країни і підготовки рішення щодо їі прийому до складу Свропейського Союзу [1, с. 5].

У побутовій український мові поняття «європеїзуватися» визначено як «ставати європейським, перебудовуватися на європейський лад, зразок» [2]. Проте цей процес є настільки громіздким, комплексним, динамічним і міждисциплінарним феноменом, що розкрити його зміст досить важко. Свропеїзація - це «модне поняття процесу змін», «суперечлива концепція», що, з одного боку, заполонила думки сучасної академічної спільноти, а з іншого - досліджена лише на рівні окремих статей та підрозділів у монографіях [3, с. 921-922; 5, с. 5-6]. Нині особливо актуальними є дослідження щодо способу здійснення європеїзації та їі юридичних наслідків.

Постановка завдання. Метою статті $є$ концептуалізація ідей європеїзації в загальногуманітарному та правовому дискурсах на основі вчень вітчизняних та зарубіжних дослідників про передумови та закономірності розвитку феномена.

Результати дослідження. Генезис і розвиток поняття «європеїзація» простежуємо в англомовній літературі про політичну інтеграцію в Свропі, де ще в 90-х роках минулого століття гостро стояло питання про те, чи впливає інтеграційний процес на інституційну трансформацію національних держав, що беруть участь у ньому. I саме в контексті пошуку відповіді на це питання і була запропонована концепція європеїзації (англ. Europeanization, нім. Europäisierung, фран. Européisation, італ. Europeizzazione, пол. Europeizacja). Межі понятійного контексту вживання цього поняття окреслені такими термінами, як європейська інтеграція, наднаціональність, багаторівневе адміністрування, інституціоналізм, Свропейський Союз (далі - СС). Очевидно, що система координат, в якій закріплений цей англомовний термін, досить конкретна й одночасно дуже далека від значень, властивих цьому поняттю в українській мові.

В європейській фаховій літературі поняття «європеїзація» вживають у кількох значеннях. Польський вчений К. Вах $(K . W a c h)$ пропонує розглядати цей феномен у 7 площинах: географічній, соціологічній, політологічній, правовій, інституційній, макроекономічній і мікроекономічній [4, с. 29]. Роздуми учений грунтує на позиції широкого розуміння європеїзації, методологічною основою якого є компаративістичний метод наукового пізнання, яке ще К. Дайсон (K.Dyson) визначив як «процес, що розвивається з часом, який включає складну взаємодію змінних елементів, що призводить до диференційованих, взаємозалежних і навіть суперечливих ефектів» [4, с. 30]. Отже, можемо стверджувати, що це соціально-культурне запозичення форм, властивих західноєвропейській традиції розвитку суспільства.

Під європеїзацією як історичним феноменом розуміють «експорт» європейської влади і соціальних норм: інституціональна організація і практика, соціальні та культурні традиції, цінності, поведінка. Так, термін «європеїзація» історики використовують для опису експорту культурних норм та взірців поведінки [3; 5]. Такий підхід поширений у науковій літературі (наприклад, у трактуванні російських учених), де європеїзація сприймається або як один із варіантів модернізації та вестернізації «зверху», або як процес свідомого сприйняття державами європейських норм і правил поведінки [6-8].

Останнім часом термін «європеїзація» став одним із найбільш часто вживаних в академічному дискурсі з міжнародних відносин, адже дослідники прагнули зрозуміти трансформації, пов'язані з європейською інтеграцією, її вплив на країни-члени СС і суміжні держави, особливо 
на країни, що пережили недемократичні режими і внутрішні конфлікти [9, с. 4]. Відповідно до сформованого в ЄС і державах-членах подання, європеїзація символізує поширення у світі загальноєвропейської політики, права, культури та інших цінностей, аби їх сприймали інші народи, держави і спільноти [10, с. 30]. 3 огляду на це, використання терміна «європеїзація» для вивчення нових рис європейської інтеграції пов'язане із т. зв. «системним ефектом» $€ С$, тобто зворотного впливу наднаціональної системи управління, створеної в Європі, на національні політичні структури держав, які її заснували й увійшли до неї.

Деякі вчені наголошують, що термін «європеїзація» може бути операційним і методологічно виправданим під час аналізу різних форм впливу інтеграційної системи на національні інститути і владні відносини тільки у співвідношенні із зарубіжною політологічною європеїстикою $[11$, c. 12,74$]$. Принагідно зазначимо, що енциклопедично термін «європеїстика» тлумачиться як галузь науки, яка зосереджується на поточному розвитку європейської інтеграції і складається із комбінації кількох сфер - політології, державної політики ЄС, європейської історії, європейського права, економіки і соціології. Найбільше заклади вищої освіти розширюють ці аспекти до тем, які містять в собі Європу, але не обов'язково європейську інтеграцію, але й, наприклад, європейську культуру, європейську літературу і європейські мови [13].

Передусім зазначимо, що термінологічно цей концепт визначається як «зближення», «посилення взаємозв'язку», тобто процес ущільнення, інтенсифікації або посилення характеристик якогось зв'язку [14, с. 257]. Щодо визначення самого процесу європеїзації, зауважимо, є різні підходи. Одна 3 перших дефініцій цього феномена належить британському політологу Р. Ладреху (R. Ladrech), який на початку 1990-х років вивчав вплив європеїзації на внутрішню політику Франції. Так, у 1994 році на шпальтах «Journal of Common Market Studies» він розглядає європеїзацію як «процес трансформації форм вироблення національної політики, що посилюється внаслідок і відповідно до того, як політичний та економічний розвиток Європейського Співтовариства стає частиною процесу ухвалення рішень на національному рівні» [15, p. 69].

Сінгапурський професор Р. Вонг ( $R$. Wong) виокремив п’ять основних шкіл, предметом аналізу яких був феномен європеїзації. Так, європеїзацію трактували: 1) як національну адаптацію (зміни «зверху вниз» - із наднаціонального на національний рівень); 2) як проєкцію національної політики (зміни «знизу вгору» і горизонтально, передача влади на наднаціональний рівень); 3) як реконструкцію ідентичності (зміни «зверху вниз», соціалізація еліти); 4) як модернізацію (зміни «зверху вниз», демократизація, вестернізація); 5) як політичний ізоморфізм (зміни «знизу вгору» і горизонтально, трансфер політики) [16, с. 150-155]. Утім, за будь-яким із цих підходів дослідники фокусуються на двох рівнях - національному, на якому відбувається переорієнтація національної політики, і наднаціональному, де створюються і розвиваються європейські управлінські структури. Тобто європеїзацію можна розглядати як рамкову концепцію, яка пов'язує на основі взаємності і внутрішні, і зовнішні аспекти розвитку європейської інтеграції.

Водночас свої трактування європеїзації пропонують західні науковці. Так, К. Деммке (Ch. Demmke) визначає цей процес як «цілеспрямовану, програмовану адаптацію або несвідоме, стихійне пристосування внутрішнього національного законодавства, процедур, норм, стандартів до норм і правил СС» [17].

На думку німецького політолога М. Тіля (M. Thiel), європеїзація держав-членів СС, тобто їхня адаптація до норм і правил $Є \mathrm{C}$, а також, у більш ширшому значенні, інтеграція - це всеохоплюючий процес, який характеризує сучасне суспільне та політичне життя в Європі [18, с. 53]. Інша німецька дослідниця Т. Борзель (T. Börzel) акцентує на «проникаючій» властивості європеїзації і процесах, завдяки яким внутрішні політики дедалі більше залежать від європейського формування політики [19, с. 573-574].

Цікавою є позиція С. Бульмера (S. Bulmer) і М. Бурха (M. Burch), які розглядають європеїзацію як «вплив європейських інтеграційних процесів на національний рівень, особливо, на національну систему органів адміністрування» [20, с. 73]. Отже, відповідно до визначень Р. Ладреха та Т. Борзель, європеїзація постає як особливе поняття, ототожнене із впливом політичного процесу, тобто європейської інтеграції, на системи публічного адміністрування. Тобто їхня позиція зосереджена винятково на діяльності СС. Тимчасом європеїзація, за С. Бульмером і М. Бурхом, проводить паралель між вибором, запропонованим країнам, які прагнуть інтегруватися до ЄС, i процесами, визначеними СС, для ухвалення низки правил, норм, інституційних структур, ідей, значень, інтересів.

Наявна література з європеїзації охоплює й розробки дослідників із питань ідентичності та демократизації. 3 огляду на це зустрічаємо твердження, що європеїзація як взаємодія наці- 
онального рівня (держави-учасниці) та наднаціонального рівня (СС) означає на практиці, що взаємодія двох рівнів посилюється через реконструкцію європейської ідентичності, яка змінює національні інтереси та національну ідентичність. Під т.зв. «реконструкцією ідентичності» вчені розуміють соціалізацію інтересів і цінностей, їх переплетення (cross loading) [16; 21]. Особливо важливим у цьому зв'язку є поняття соціалізації. У загальному сенсі соціалізація означає сприйняття дійовою особою смислів і правил учасника якогось співтовариства. Коли ж мова йде про держави, що вступили в інтеграційний процес, то соціалізація має на увазі європеїзацію, тобто перенесення на внутрішньополітичну арену законів і звичаїв, за якими живе європейське регіональне співтовариство [22, с. 43].

Загалом в європейській доктрині є кілька варіантів використання цього терміна. Так, за Р. Хармсен (R. Harmsen) і T. Вільсон (T. Wilson) [23, с. 14]:

1) європеїзація як поява нових форм європейського адміністрування. У цьому сенсі європеїзація фокусується тільки на $Є С$ з акцентом на тому, як європейська інтеграція зумовлює перегляд концепцій, відносин і структур влади, як на внутрішньодержавному, так і на рівні ЄС. Європеїзація цього типу звертає увагу на зусилля ЄС щодо публічного будівництва (policy building) i на створення справжнього громадського простору (public space) [23, p. 14];

2) європеїзація як національна адаптація. Тут під європеїзацією розуміють адаптацію структур і процесів на державному рівні як реакцію на європейську інтеграцію. Європеїзація показує, чи стають подібними між собою внутрішньодержавні структури країн-членів СС у результаті процесів транснаціонального запозичення або копіювання європейської моделі [19, с. 583];

3) європеїзація як політичний ізоморфізм. Цей варіант концепції стосується ступеня конвергенції (convergence) в різних сферах політики. Італійський науковець К. Радаеллі (C. Radaelli) вважає, що європеїзація має два виміри: «прямий», тобто передача регуляторної компетенції 3 рівня країн-членів $Є С$ на наднаціональний рівень і «непрямий»- копіювання країнами-членами один одного [24, с. 553]. У цьому руслі деякі автори говорять про можливу динаміку «політичного ізоморфізму» [25, с. 26];

4) європеїзація як проблема і можливість для внутрішньополітичного менеджменту. Проблемні моменти виражаються в тому, що уряди мають стикувати потенційно суперечливі впливи з боку СС та внутрішньодержавних акторів; можливості проявляються в тому, що уряди можуть брати участь у «дворівневих іграх» [26, с. 81$]$;

5) європеїзація як модернізація. У цьому сенсі термін «європеїзація» застосовується до географічно більш периферійних й економічно менш розвинених держав-членів, що допускає структурні трансформації для того, щоб вивести ці держави з периферії, і визначає їх на основі економічних і політичних моделей, що превалюють у більш розвинених і впливових державах $[26$, c. 81$]$;

6) європеїзація як «приєднання до Європи», тобто цей концепт сприймається в контексті розширення ЄС. Найчастіше в цьому розумінні концепція застосовується до прийняття державами-кандидатами Центральної та Східної Європи західноєвропейської державної моделі [26, с. 84].

Вітчизняні науковці ж застосовують термін «європеїзація» переважно для осмислення та аналізу змін у внутрішній політиці тієї чи іншої держави, спричинених процесом європейської інтеграції. Так, дослідник О. Рудік визначає європеїзацію як зміни, що відбуваються в усіх сферах суспільного життя держав-членів або держав-кандидатів під впливом процесу європейської інтеграції. Різні концепції процесу європеїзації, на думку вченого, більше доповнюють, ніж заперечують одна одну. Вони стосуються різних, але пов'язаних явищ. Динаміка європеїзації може бути осмисленою на основі обмеженої групи звичайних процесів змін, які є взаємодоповнювальними й добре відомими в інших системах управління. Водночас приклад ЄС є ілюстрацією того, як звичайні процеси здатні привести до неочікуваних результатів [27, с. 6].

Як зазначають Д. Міхель, І. Беца та Л. Шереметьєва, європеїзація - це побудова, поширення й інституціоналізація офіційних і неофіційних правил, процедур, політичних стилів і спільних вигод і норм, які вперше були визначені й консолідовані в процесах ЄС і Ради Європи, а потім уведені в логіку українських внутрішніх політичних структур і державної політики на шляху інтеграції України до ЄС [28, с. 25; 29, с. 36]. Таке визначення видається більш прийнятним, оскільки враховує той факт, що інтеграція до ЄС - це інтерактивний процес, в якому уряд України, втілюючи європейський вибір, не тільки отримує мотивацію і політичні директиви ЄС, але й бере участь у створенні переговорного порядку, коли інтеграція до ЄС визначає внутрішні політики і політичне життя посткомуністичних держав. У рамках цього узгодженого порядку Україні треба спроєктувати свої інтереси так, щоб визначити траєкторію інтеграції і задовольнити національні інтереси в рамках Плану дій Україна - СС і попереднього членства в Раді Свропи [29, с. 37]. 
Вітчизняна дослідниця Д. Дворніченко визначає європеїзацію як процес трансформації власних та оволодіння колективними європейськими політичними та управлінськими практиками, пріоритетами, настановами, нормами, стандартами та цінностями як країнами-членами, так $\mathrm{i}$ країнами-кандидатами на вступ до ЄС у процесі європейської інтеграції [30, с. 12].

У цьому контексті варта також уваги позиція норвезького вченого Дж.П. Олсена (J.P. Olsen), який зосередився на комплексному характері процесу європеїзації і тлумачить його з урахуванням щонайменше п’яти потенційних проекцій, які вживаються для розкриття різних, але споріднених між собою явищ:

1) зміни і розширення зовнішніх кордонів $\mathrm{CC}$ : формування єдиного політичного простору в Європі як континенті з єдиними правилами врядування;

2) розвитку організаційних інститутів на європейському рівні, що функціонують на принципах координації та конвергенції;

3) проникнення європейського порядку до національних і наднаціональних систем врядування, які грунтуються на принципах відповідальності та дієвості багаторівневої моделі врядування;

4) експорту європейської моделі політичної організації та врядування за межі Європи у прямій та опосередкованій формі;

5) політичного проекту уніфікації $\mathrm{CC}$, що передбачає функціонування єдиного сильного гравця на континенті з чіткими географічними кордонами, єдиними централізованими правилами врядуванням тощо [3, с. 921]. Тож, на думку ученого, європеїзація може виражатися в зміні територіальних кордонів ЄС унаслідок входження до нього нових держав-членів [3, с. 944]. Утім, виражена в цьому визначенні позиція радше викликає питання, ніж сприяє знаходженню відповідей на них. Труднощі, з якими стикаються дослідники, пов'язані, зокрема, зі з'ясуванням характеру взаємозв'язку між європеїзацією та інтеграцією. Іншими словами, немає чіткості в тому, чи є європеїзація наслідком європейської інтеграції чи ці процеси ідентичні. Це питання вже тривалий час перебуває в центрі уваги науковців [31], проте однозначної відповіді на нього поки немає. Визначення європеїзації як зміни географічних кордонів $\mathrm{CC}$, безумовно, структурує програму дослідницької роботи в напрямі теорій європейської інтеграції, особливо в контексті аналізу причин вступу Великобританії в Європейське економічне співтовариство, який здійснив E. Xaac (E.B. Haas) [32].

Уважаємо, що Дж.П. Олсен $є$ послідовним в ототожненні інтеграції і низки проявів європеїзації, визначаючи останню як розвиток інститутів політичного врядування на наднаціональному рівні [3, с. 951]. Отже, поглиблення європейської інтеграції, як і їі розширення, можна розглядати як європеїзацію національної держави. Такий підхід, безумовно, має свої переваги: він має універсальний характер і надає змогу систематизувати всі явища, які можуть призвести до трансформації національних інститутів.

Концепт європеїзації дослідники використовують у різних контекстах і з різними значеннями. Так, Т. Лоутон (T. Lawton) проводить відмінності між «європеїзацією», тобто де-юре передачею суверенітету на рівень $Є C$, i «європефікацією», тобто де-факто поділом повноважень між національними урядами та Брюсселем [33, c. 36]. С. Хікс (S. Hix) і К. Гетц (K. Goetz) вважають, що європеїзація - це «процес зміни національних інституційних і політичних практик, приписуваний європейській інтеграції» [34, с. 4]. Т. Борзель же визначає європеїзацію як «процес, у результаті якого різні сфери національної політики стають суб'єктами Європейського політичного процесу» [19, с. 574]. Ще інше визначення пропонують Т. Picce (T. Risse), М.Г. Коулз (M. G. Cowles) і Дж. Капорасо (J. Caporaso): «Європеїзація - це виникнення і розвиток на загальноєвропейському рівні різних структур урядування, тобто політичних, юридичних і соціальних інституцій, пов'язаних із політичним вирішенням проблем, що формалізує взаємодію акторів, а також політичних систем, що спеціалізуються на створенні обов'язкових європейських правил» [35, с. 3].

Як зазначає К. Радаеллі, акцент на «створенні правил» і «європейському рівні» зумовлює надто широке розуміння європеїзації, що охоплює політику ЄС і іiї вплив на національні системи, і в певному сенсі може бути прирівняне до формування політики $Є С$ та європейської інтеграції [33, c. 29]. Із цих підстав європеїзація в баченні німецького вченого У. Фастенрата (U. Fastenrath) означає «взяти під сумнів власне національне рішення» [36, с. 277]. Тому, за зауваженням угорської дослідниці А. Вінце (A. Vincze), вплив процесу, задекларованого як європеїзація, визначається характерними особливостями національного правопорядку. Тому й на вимоги, що випливають з європейського права, правопорядки держав-учасників реагують по-різному, причому ці відмінності не завжди можуть пояснюватися значущістю гарантій правила «юридичної сили» в національному адміністративному праві [37, с. 235]. 
Згадуваний уже Р. Ладрех підходить до цієї концепції з більш загальних позицій, акцентуючи на національній ідентичності та європеїзації як процесі. Він визначає європеїзацію як «поступальний процес, що переорієнтує напрям і форму політики до тієї міри, що динаміка політичного й економічного розвитку Європейських Співтовариств стає частиною організаційної логіки політики та процесу її формування на рівні країн-членів» $[15$, с. 70$]$. Під «організаційною логікою» він розуміє «адаптивні процеси організацій до зміненого або змінюваного навколишнього середовища» $[15$, с. 71$]$, підкреслюючи тим самим важливість адаптації, навчання та зміни політики. Недолік цього визначення полягає в тому, що занадто сильний акцент на організації може невиправдано принизити роль індивідуумів й агентів змін [33, с. 30].

Грунтуючись на цьому розумінні терміна, К. Радаеллі визначає європеїзацію як «процеси (a) конструювання, (b) поширення і (c) інституціоналізації формальних і неформальних правил, процедур, управлінських парадигм, стилів управління та поділюваних переконань і норм, які спочатку визначаються і консолідуються в європейському політичному процесі і потім інкорпоруються в логіку національного дискурсу, ідентичностей, політичних структур і публічної політики» $[33$, с. 30]. На його переконання, усі цінності спочатку визначаються й узгоджуються під час політичного процесу на рівні $\mathrm{CC}$, а потім інкорпоруються в національний політичний процес [38, с. 17]. К. Радаеллі пропонує розглядати європеїзацію як наслідок європейської інтеграції, тобто як процес, який стартував після досягнення якоїсь «критичної точки» в політичному об'єднанні Європи. Після набуття чинності Маастрихтським договором 1992 року зворотний вплив наднаціональної системи управління на національні держави перестав бути галузевим і програмованим, а перетворився на масштабний і неоднозначний.

Як бачимо, підхід до визначення терміна «європеїзація» К. Радаеллі є найбільш комплексним: «Європеїзація складається з процесів творення, поширення та інституціоналізації формальних і неформальних правил, процедур, політичних парадигм, стилів, «того, як робляться справи», і спільних переконань та норм, які спочатку визначаються й утверджуються в політичному просторі $\mathrm{CC}$, а потім вводяться в логіку внутрішньодержавного (національного й наднаціонального) дискурсу, політичних структур і публічних політик» [39, с. 58]. Це визначення може здатися недостатньо конкретним і занадто всеосяжним, однак воно підкреслює важливість змін не тільки в політиці, але і в структурах, що лежать в основі державного устрою, в ідентичності. Європеїзація охоплює асиміляцію європейської політики, а тому відноситься і до інституціалізації. На відміну від більшості підходів до європеїзації, що обмежують зону ііі дії країнами-членами ЄC [40, с. 4], це визначення можна застосовувати і до держав поза ЄС [41, с. 303]. Це важливо, оскільки у дослідженні автор оцінює перспективи, розглядаючи їх як приклад процесу європеїзації, а Україна поки не є державою-членом ЄС. Отже, термін «європеїзація» варто тлумачити відповідно до визначення, яке запропонував К. Радаеллі.

Отже, якщо брати за основу те, що витоки європеїзації лежать на європейському континенті, тоді всі суб'єкти, що на ньому розташовані, приймають (поглинають) все, що є дійсно «європейським» (культуру, історію, політику, право). Але нині цей термін тлумачиться набагато глобальніше: він застосовується до широкого кола відносин, характеризуючи внутрішні і зовнішні трансформації держави та суспільства. Внутрішнім проявом європеїзації, як зазначає український вчений Р. Петров, є вплив динамічного acquis $\mathrm{EC}$ на правопорядок держав-членів ЄС, а також необхідність наближення їхніх інституційних та правових інститутів до вимог ЄС. Водночас зовнішнім проявом європеїзації дослідник вбачає зростання ролі ЄС як глобального гравця [45, с. 325].

Неодноразово ЄС у своїх документах наголошував, що зовнішня політика щодо третіх країн має грунтуватися на ідеї (концепції) європеїзації. Так, яскравим прикладом європеїзації $є$ адаптація «акцесійного» acquis ЄС низкою країн Центрально-Східної Європи, що було частиною виконання критеріїв членства в ЄС. Однак поширення європейських спільних демократичних цінностей у третіх країнах, до яких застосовується підхід СС «інтеграція без повного членства», створення спільного економічного, політичного та правового простору, $є$ надзвичайно складним завданням. Зрозуміло, що ЄС сприяє європеїзації, але ефективність та результативність цього процесу залежать від готовності та спроможності третіх країн «європеїзуватися». Це стосується, передусім, країн Східного партнерства, зокрема Грузії, Молдови та України.

Однак дехто з дослідників сумнівається в позитивному впливі європеїзації на процес консолідації демократії, оцінюючи розширення СС як неоколоніальний чи неоімперський проєкт, що здійснюється в «неовізантійському» стилі. На їхню думку, зусилля центральноєвропейських еліт щодо якнайшвидшого i, що найважливіше, результативного завершення переговорів з $\mathrm{C}_{\text {в- }}$ 
рокомісією підірвали процес демократичного вироблення політики всередині суспільства, заперечивши право частини груп інтересів ставити під сумнів привабливість європейського проєкту. Як наслідок, постсоціалістичні країни набули ознак слабких не підконтрольних громадянам демократій, в яких суспільство розчарувалося одночасно і в Свропі, і в демократії.

Наводиться аргумент, що, можливо, в короткостроковій перспективі процес європеїзації і матиме позитивні наслідки, проте у.довгостроковій - штучно стимульований вступ до ЄС матиме згубні наслідки для демократії. Ї̈̈ консолідація підірвана обмеженням публічних дебатів щодо вигоди та втрат від приєднання до європейського простору, відвернення частини соціально-політичних акторів від формування політичного порядку денного, руйнування системи підконтрольності влади власне громадянам, а не наднаціональним структурам. 3 огляду на це виникли й більш песимістичні думки щодо того, що найближчими роками в багатьох країнах виникне тенденція до деєвропеїзації [42, с. 18]. Це пов'язано з тим, що європеїзація, на думку політологів-скептиків, звелася до експорту феномена «дефіцит демократії» з СС до країн Центральної Європи, що спричинило ризики для історичної можливості створити в регіоні легітимні демократичні режими «учасницького» типу [43, с. 112].

Утім, вважаємо, заслуговує на увагу так званий «компромісний» підхід, який пропонує, з методологічного погляду, перелік питань, які треба дослідити, щоб визначити позитивні й негативні наслідки європеїзації. Як вказують окремі вчені, для досягнення оптимальної - для певного національного суспільства - залежності між двома процесами, потрібно знайти відповідь на набір соціально-політичних викликів. Серед них - виклик реформування політичних інститутів (держави, місцевого самоврядування, політичних партій), які мають бути здатні гармонізувати інтереси національних соціально-політичних акторів і норми, сформовані ЄС, створити такі механізми підконтрольності громадянам, щоб, з одного боку, уникнути спокуси популізму, основаного на євроскептицизмі, а з іншого - бути здатними просувати інтереси груп у середовищі європейських керівних інститутів. Важливою є також здатність політичної системи зберегти підзвітність виконавчої влади перед парламентом у питаннях, що стосуються європейської політики, сформувати канали вертикальної комунікації з регіональними та місцевими властями, що мають власні потреби щодо інтеграції в єдиний простір континенту. Ще більш складним завданням $є$ інтернаціоналізація нових інститутів, створених упродовж обмеженого відрізка часу бюрократією та громадянами для того, щоб вони не сприймалися як «чужорідне тіло» [44; 2].

Висновки. Отже, процес європеїзації сучасного суспільства - це модерні динамічні процеси, в яких задіяні внутрішні інституції та інституції $\mathrm{CC}$, що проявляються у змінах в політиці, пріоритетах і спрямованості. Процес інтеграції в ЄС для кожної держави щораз більш ускладнюється з огляду на глобалізаційні та євроінтеграційні зміни. Тому поняття «європеїзація» є багатогранним і багатовекторним, яке передбачає різні напрями ії реалізації. Нині $є$ конкуренція між безліччю підходів до визначення цього феномена, свідченням чого $є$ те, що процес європеїзації вивчено далеко не в усіх його проявах. Підбиваючи підсумок, можемо сказати, що європеїзація, як правило, $\epsilon$ ієрархічним (англ. «top-down») впливом, що концентрується на перенесенні європейських норм і стандартів на рівень інших держав. Хоча більшість дослідників фокусує увагу тільки на країнах-членах ЄС, немає підстав вважати, що процеси європеїзації не можуть відбуватися поза ним, зокрема в Україні. Деякі дослідники вже застосовували цей концепт у процесі вивчення держав-сусідів ЄС.

\section{Список використаних джерел:}

1. Савельєв Є. Європейська інтеграція чи європеїзація? Журнал європейської економіки. 2008. T. 7, № 1 . C. 3-5.

2. Словник української мови: в 11 т. / АН УРСР, Ін-т мовознавства ім. О.О. Потебні; редкол.: І.К. Білодід (голова) [та ін.]. Київ : Наук. думка, 1970-1980. Т. 2: Г-Ж. 1971. 550 с.

3. Olsen J.P. The Many Faces of Europeanization. Journal of Common Market Studies. 2002. Vol. 40, № 5. P. 921-952.

4. Wach K. Wymiary europeizacja i jej kontekst. Zeszyty Naukowe Uniwersytetu Ekonomicznego w Krakowie. 2011. № 852, S. 29-43.

5. Featherstone K. Introduction: In the Name of «Europe». The Politics of Europeanization / ed. K. Featherstone, C.M. Radaelli. Oxford: Oxford University Press, 2003. P. 1-26.

6. Латкина В.А. Феномен европеизации в западноевропейских исследованиях. Международные проиессы. 2013. № 1 (32). С. 49-62.

7. Бордачев Т.А. Россия и Евросоюз: проблема европеизации. Современная Европа. 2006. № 4. C. $120-129$. 
8. Громогласова Е.С. Концепция европеизации в зарубежной политологии. Вестник Московского университета. Сер. 25: Международные отношения и мировая политика. 2010. № 4. C. 27-43.

9. Emerson M. Europeanisation as a Gravity Model of Democratisation. Centre for European Policy Studies. Working Document. 2004. 1 Nov. № 214.31 p.

10. Дерябина Е.М. Европеизация международного публичного права: основные формы. Вестник МГОУ. Сер.: «Юриспрудениия». 2012. № 3. С. 29-33.

11. Гудзь М.В., Гудзь П.В. Загальний курс європеїстики : навч. посібник. Донецьк : Юго-Восток, 2006. 274 с.

12. Антонюк Н., Мальська М. Основи європеїстики: посібник. Львів, 2014. 348 с.

13. Свропеїстика. Вікіnедія. URL: https://uk.wikipedia.org (дата звернення: 29.07.2019).

14. Айзінг Р. Європеїзація та інтеграція. Концепти дослідження ЄС. Європейська інтеграція / уклад.: М. Яхтенфукс, Б. Колєр-Кох; пер. $з$ нім. М. Яковлєва. Київ : Вид. Дім «Києво-Могилян. акад.», 2007. С. 255-274.

15. Ladrech R. Europeanization of Domestic Politics and Institutions: The Case of France. Journal of Common Market Studies. 1994. Vol. 32, № 1. P. 69-88.

16. Wong R. The Europeanization of Foreign Policy. International Relations and the European Union / eds. C. Hill, M. Smith. $2^{\text {nd }}$ ed. Oxford: Oxford University Press, 2011. P. 150-170.

17. Demmke Ch. Undefined Boundaries and Grey Areas: The Evolving Interaction Between the EU and National Public Services. Eipascope. 2002. No. 2. URL: http:/www.eipa.nl (дата звернення29.07.2019).

18. Thiel M. The Limits of Transnationalism: Collective Identities and EU Integration. New York : Palgrave Macmillan, 2011. 244 p.

19. Börzel T. Towards Convergence in Europe? Institutional Adaptation to Europeanization in Germany and Spain. Journal of Common Market Studies. 1999. Vol. 37, № 4. P. 573-596.

20. Bulmer S., Burch M. The «Europeanisation» of Central Government: the UK and Germany in Historical Institutional Perspective. The Rules of Integration / M. Aspinwall, J. Scheider (eds). Manchester : Manchester Univ. Press, 2000. P. 73-96.

21. Wong R. Foreign Policy. Europeanization: New Research Agendas / P. Graziano and M.P. Vink (eds.). New York : Palgrave Macmillan, 2007. P. 321-334.

22. Стрежнева М.В. Теории европейской интеграции. Вестник Моск. ун-та. Сер. 25: «Междунар. отношения и мировая политика». 2009. № 1. С. 28-45.

23. Harmsen R., Wilson T. Introduction: Approaches to Europeanization. Yearbook of European Studies «Europeanization». 2000. Vol. 14. P. 13-26.

24. Radaelli C. How Does Europeanization Produce Domestic Policy Change? Corporate Tax Policy in Italy and the United Kingdom. Comparative Political Studies. 1997. Vol. 30, № 5. P. $553-575$.

25. Radaelli C. Policy Transfer in the European Union. Institutional Isomorphism as a Source of Legitimacy. Governance: An International Journal of Policy and Administration. 2000. Vol. 13, № 1. P. $25-43$.

26. Harmsen R. The Europeanization of National Administrations: A Comparative Study of France and the Netherlands. Governance: An International Journal of Policy and Administration. 1999. Vol. 12, № 1. P. 81-113.

27. Рудік О. Європеїзація як процес та предмет досліджень. Європеїзація публічного адміністрування в Україні в контексті європейської інтеграції : матеріали наук.-практ. конф., м. Дніпропетровськ, 17 груд. 2009 р. / за заг. ред. Л.Л. Прокопенка. Дніпропетровськ : ДРІДУ НАДУ, 2009. C. 6-10.

28. Міхель Д.О. Визначення поняття процесу «європеїзація» та його вплив на сучасне суспільство. Наукові праці Чорноморського державного університету імені Петра Могили. Сер.: Політологія. 2011. Вип. 150, Т. 162. С. 22-25.

29. Беца І., Шереметьєва Л. Основи поняття «європеїзація» та його сенс у сучасному суспільстві. Свропеїзація публічного адміністрування в Украӥні в контексті європейської інтеграuзiі : матеріали наук.-практ. конф., м. Дніпропетровськ, 17 груд. 2009 р. за заг. ред. Л.Л. Прокопенка. Дніпропетровськ : ДРІДУ НАДУ, 2009. С. 36-39.

30. Дворніченко Д.Ю. Свропеїзація внутрішньої та зовнішньої політики Греції в контексті європейського інтеграційного процесу : автореф. дис. ... канд. політ. наук. Одеса, 2013. 20 с.

31. Radaelli C. Whither Europeanization? Concept Stretching and Substantive Change. European Integration Online Papers. 2000. Vol. 4, № 8. URL: http://eiop.or.at/eiop/texte/2000-008a. htm (дата звернення: 29.07.2019). 
32. Haas E.B. The Uniting of Europe: Political, Social and Economic Forces, 1950-1957. Stanford, 1958. $641 \mathrm{p}$.

33. Radaelli C. Europeanization of Public Policy. The Politics of Europeanization / K. Featherstone, C. Radaelli (eds.). Oxford : Oxford University Press, 2003. P. $27-56$.

34. Vink M. What is Europeanization? and Other Questions on a New Research Agenda. Paper for the Second YEN Research Meeting on Europeanisation. Milan : University of Bocconi. 2002. November, 22-23.

35. Risse T., Cowles M.G., Caporaso J. Transforming Europe: Europeanization and Domestic Change (Cornell Studies in Political Economy). Ithaca, New York : Cornell University Press, 2001. $304 \mathrm{p}$.

36. Fastenrath U. Die veränderte Stellung der Verwaltung und ihr Verhältnis zum Bürger unter dem Einfluß des Europäischen Gemeinschaftsrechts. Verwalt, 1998. 306 b.

37. Vincze A. Europäisierung des nationalen Verwaltungsrechts - eine rechtsvergleichende Annäherung. Zeitschrift für ausländisches öffentliches Recht und Völkerrecht (ZaöRV). 2017. B. 235-268.

38. The European union and member states: towards institutional fusion? / ed. Dietrich Rometsch D., Wessels W. Manchester : Manchester univ. press, 1996. 382 p.

39. Börzel T., Risse T. Conceptualizing the Domestic Impact of Europe. The Politics of Europeanization / K. Featherstone, C.M. Radaelli (eds.). Oxford : Oxford University Press, 2003. P. 57-80.

40. Schimmelfennig F., Sedelmeier U. Introduction: Conceptualizing the Europeanization of Central and Eastern Europe. The Europeanization of Central and Eastern Europe / F. Schimmelfennig, U. Sedelmeier (eds.). Ithaca, New York : Cornell University Press, 2005. P. 1-28.

41. Grabbe H. Europeanization Goes East: Power and Uncertainty in the EU Accession Process. The Politics of Europeanization / K. Featherstone, C. Radaelli (eds.). Oxford : Oxford University Press, 2003. P. 303-328.

42. Germany`s EU Policy on Asylum and Defence: De-Europeanization by Default? / ed. G. Hellmann. New York : Palgrave Macmillan, 2006. 238 p.

43. Democratic Consolidation in Eastern Europe. International and Transnational Factors / ed. A. Pravda, J. Zelionka. Oxford : Oxford Univ. Press, 2001. Vol. 2. 372 p.

44. Ekiert G. Dilemmas of Europeanization: Eastern and Central Europe after the EU Enlargement. Acta Slavica Iaponica. 2008. T. 25. P. 1-28.

45. Petrov R., Kalinichenko P. The Europeanization of third country judiciaries through the application of the EU acquis: the cases of Russia and Ukraine. International \& Comparative Law Quarterly. № 60 (2). P. 325-353. 